\title{
DIE ONTWRIGTING VAN DIE AFRIKANERVOLK EN VOLKSEENHEID.
}

Die gevare wat ons Afrikanerdom voor die deur staan, is baie en ernstig. Daar is die gevaar van immigrasie van buitelanders, daar is die al driester geroep om gelykstelling tussen blank en gekleurd, daar is die dreigende oorheersing van 'n oppervlakkige Amerikaanse ,jazz"-gees.

Maar die grootste van alle gevare is wel die verwording van die Afrikanerdom self. Kapitalisme is nie soos baie meen 'n dooie mossie nie, nee nou eers begin dit sy kragte ten volle ontplooi in Suid-Afrika. Terwyl sy mag bykans uitgewoed is in Europa en slegs die laaste stuiptrekkings daarvan gesien word, is dit nou besig om geweldiger as ooit te vore ons kuste tot oor ons berge te oorspoel. Sy vlerke word nou wyd en ver oor ons dierbare land uitgeslaan.

In die verlede was dit nog altyd 'n vreemde mag wat buite ons gestaan het en wat ons duidelik en skerp as 'n vyand onderskei het, maar nou is dit binne ons poorte en ons Afrikaners self word besmet met hierdie gees uit die afgrond. Ons word geïndividualiseer en ons leef as enkelinge was saangesleur word deur die stroom van hierdie gees. Ons het geen eie bedding waarin ons volkstroom sterk en kragtig en suiwer kan vloei nie. Baie van ons is nog slegs toeskouers van 'n kultuur wat voor ons ontwikkel, maar self het ons geen eie kultuurlewe nie. Ons daaglikse lewe en ons godsdienstige lewe word twee heeltemal afgesonderde terreine. Sondag is 'n deel-'n klein deel-van ons nog in die kerk, maar Maandag stap ons oor in 'n heeltemal ander lewe. Die kerk self het al minder voeling met die lewe daar buite. Ons enigste strewe word na kos, klere, 'n nuwe motorkar, 'n nuwe draadloostoestel en nog baie ander 
60

nuwe en pragtige dinge wat ons kan verkry. Ons leef in die teken van die geweldige kragsontplooiing van die atoomkrag van hierdie kapitalistiese aanstorming oor ons land. Ons strewe is om self kapitaliste te word en daar is al baie Afrikaners wat hul mede-Afrikaners uitbuit. Ons vra nie na die heil van ons mede-Afrikaners nie, dit is elkeen vir homself.

Hoe kan die Afrikaner onder sulke omstandighede nog 'n eie beeld vertoon met 'n eie kultuur? Hoe kan die Afrikaner godsdienstig bly as hy gedurig in aanraking is met 'n ongodsdienstige kultuur en as hy gedurig bloot gestel word aan die suigkrag van die vermeende aanloklikhede van 'n sterke uitheemse en onchristelike kapitalistiese gees?

Die Afrikaner word los van sy eie volksbestaan en die gevolg sal wees dat hy ook los word van sy kerk. 'n Geïndividualiseerde mens kan moeilik nog godsdienstig bly. Ons kerke in die groot stede word vandag slegs enkele oliekolle wat dryf op die onmeetlike kapitalistiese see.

Teenoor hierdie kapitalisme het daar reeds in die wêreld 'n rewolusic ontstaan en dit het begin in Rusland vanwaar die kommunisme deurgeslaan het tot in Wes-Europa en vandag gepropageer word in alle lande van die wêreld. Duitsland, wat seker meer as 'n ander land kennisgemaak het met die euwels van die kapitalisme, het ook hierdie kommunisme aangegryp as 'n redmiddel uit die nood, maar dit het ook ervaar die euwels hiervan, en om sowel kommunisme as kapitalisme nit te skakel, het die Duitse volk onder leiding van Hitler die toevlug geneem tot Nasionaalsosialisme, en so het 'n kontra-rewolusie ontstaan, maar hierdeur is ook weer die deur oopgelaat vir ander noodlottige konsekwensies.

Kommunisme word dus aangegryp as 'n magsmiddel teen die kapitalisme om hierdie kwaad vir goed uit te roei, maar hierdie kommunisme wil slegs die liggaam voed en laat die gees arm en kaal en dit is dus hierin verwant aan die kapitalisme. Terwyl dit bloot materialisties is en veral stoflike voordele aan die armer mense wil aanbied, vind dit geredelik ingang by hierdie dele van die mensdom.

Ook in Suid-Afrikan vind dit al meer en meer ingang. Dit is die natuurlike beloop van omstandighede wat deur ons self geskep is. Want as ons self kapitalisties en individualisties aangelê word en as ons eie volkslewe en kultuur 'n kragtelose en geïsoleerde verskyning word, waarby kan die Afrikaner aansluit om heldere en kragtige ideale na te streef?

Daar is vandag baie Afrikaner-werkers wat heeltemal bolsjewisties gesind is, enkele van die leidende kommuniste is Afrikaners, duisende sou kommunisties gewees het was dit nie vir die gelykheidsbeginsel van die kommunisme nie. Ons hoop en vertrou dat die kleurgevoel van die Afrikaner hom sal vrywaar van hierdie verderflike leer, maar as hierdie kleurgevoel al is warop ons staat maak, staan ons saak inderdaad baie, 
baie swak. By baic Afrikaners is die kleurgevoel as gevolg van ekonomiese ellende en gelykheid met die naturel al besig om af te stomp, en as die ekonomiese chaos en depressie kom wat ons verwag, sal die mensdom dan skrik vir kleurgelykheid as hulle kommunisme aanvoel as die enigste redmiddel uit die armblankedom? Sal die armes dan huiwer as hulle reeds gedenasionaliseer en ontwrig is? $\mathrm{En}$ al huiwer hulle vir hierdie gelykstellingsbeginsel van die kommunisme, dan nog sal die kommunisme hom wel op een of ander wyse aanpas by die Afrikaner deur nie sosiale gelykstelling te bepleit nie.

Tensy God dit verhoed, gaan ons ou volkie verskeur en verdeel word soos nooit tevore nie. Om nou die fatalistiese houding in te neem dat die Afrikaners met die verwagte depressie vanself sal saamstaan, is sondig en uiters dwaas. As dinge ontwikkel soos nou, gaan ons 'n klein minderheid van Afrikaners kry wat nog vasstaan by hul tradisies en hul kultuur en godsdiens: 'n groot deel sal kapitalisties en liberalisties en gedenasionaliseer word en 'n groot deel gaan kommunisties wees.

Hierdie ontwrigting sal sy volle afmetings aanneem omdat die Afrikaner nie in 'n eie nasionale lewensatmosfeer beweeg nie. In sy algemene genade het God die mens geplaas in ' $n$ huisgesin, ' $n$ volk en in ander sosiale verbande en die bedoeling van die Here hiermee is om die volle uitwerking van die sonde te temper en ook om die mens te leer om so in sosiale verband met sy medemense Hom te leer ken en te dien en om cns pligte teenoor ons naaste te vervul. Wat ons volk betref, het die Here ons 'n kultuur en tradisies gegee wat in gees en rigting nog Christelik genoem kan word. Aangesien die oorsaak van die geestelike, sedelike en sosiale ontwrigting van die Afrikaner hoofsaaklik daarin geleë is dat hy gedenasionaliseer word en daar nie 'n eie volkslewe is nie, spreek dit vanself dat, om die ontwrigting te verhoed, die Afrikaner weer genasionaliseer moet word.

En dan moet daar ook ' $n$ eie volksbedding wees waarin die volkslewe kan stroom. Nou kom hierdie volkslewe nog net soos 'n dowwe flikkering met volksfeeste te voorskyn, en dan is daar met eleksietye so'n klein aardbeu ing. en dan is alles weer verby en ons is weer instrumente van 'n volksvreemde gees. As ons kultuur en tradisies gesond is en as dit die aangewese weg is dat ons Afrikaners genasionaliseer moet word, walar is die volk dan wat draer hiervan moet wees? Ons het baie partye en organisasies, individue word bearbei, maar ons volk self raak verlore onder al die aktiwiteite. Die volk self moet ook as objek van bearbeiding geneem word. Dic volk self moet beweeg en daar moet weer 'n tie volksatmosfeer geskep word. 
Hieruit volg vanselfsprekend dat ons Afrikaners moet saamstaan en 'n eenheidsfront vertoon nie alleen om die vreemde magte die hoof to bied nie, maar ook om ons eie Afrikaners te behou vir 'n eie volkslewe.

Nasionalisering, skepping van 'n eie volksbedding en volkseenheid-hierdie drie beskou ons dus as essensiële voorwaardes vir die behoud van die Afrikanerdom. Alleen wanneer dit geskied, sal ons die uitlanders die hoof kan bied, ons eie probleme kan oplos, ons eie land regeer en ook ons eie Afrikaners red van geestelike, sedelike, ekonomiese en sosiale ontwrigting. Nasionalisering, skepping van 'n eie volksbedding en van volkseenheid kan alleen geskied as die volk saamgesnoer word in 'n hegte volksbeweging.

Dit beskou ons as die enigste uitredding vir die Afrikaanse volk. As ons dit nie doen nie, sal ons Afrikaners al meer en meer ontwrig en geïndiwidualiseer word en ons volk sal uitmekaar geskeur word in kapitaliste en kommuniste. Dan sal dit nie meer moontlik wees om 'n gesonde volksbeweging te stig nie, dan het daar ontstaan die skeiding tussen lig en duisternis en van 'n Christelike Afrikanervolk sal daar dan nie meer sprake wees nie. Nou is daar nog die moontlikheid dat ons kan saamstaan, nou is daar nog 'n groot mate van inwendige eenheid onder ons Afrikaners, maar as die magte uit die bose eers in hul volle werking oor ons land losgelaat word, sal dit te laat wees.

Inwendig is daar ten spyte van al die uitwendige verdeeldhede og 'n diepere eenheid. Daarvoor kan ons God nooit genoeg dankbaar wees nie. Was dit nie daar nie, sou volkseenheid 'n onmoontlikheid wees. Hierdie eenheid is gebaseer op ons Christelik-nasionale beginsels en is dus nog 'n gesonde eenheid. Was dit 'n eenheid wat gebaseer is op die beginsels van die duisternis, sou ons slegs die roeping gehad het om te red wat gered kan word. Maar nou is daar nog 'n gesonde, inwendige eenheid en daarom is dit ook moontlik om te arbei vir 'n volle openbaring van hierdie eenheid. Daar is wel afvallige en beginsellose Afrikaners, maar hulle is slegs takke wat van die boom afgeval het. Die boom self staan nog en is nog gesond. Daar is takke van die boom in alle kerke, in alle partye en in alle Afrikaanse organisasies.

Dat daar so'n inwendige eenheid is, het ten duidelikste tot openbaring gekom met die Eeufees en daarna in die O.B. Spontaan het ons volk weer bymekaar gestaan en daar was geen beginselverskille tussen ons nie. Ons volk het 'n gesonde en Christelike pad ingeslaan en geen aardse mag kon ons gekeer het nie.

Maar nou is ons weer verdeeld in partye, organisasies en klieke en die verdeeldheid slaan deur tot in die kerke. Almal wat nie voel soos ons klieke dink en handel nie is verraaiers, manne wat eertyds geëer was, word nou verdoem as die uitvaagsel van die land. 
Ons is almal daaroor eens dat ons Afrikaners weer genasionaliseer moet word en ook is die meeste van ons seker oortuig daarvan dat dit noodsaaklik is dat ons tot volkseenheid moet kom. Maar nasionalisering van die Afrikaner sal nie plaasvind alleen as gevolg van indiwiduele bearbeiding nie, en volkseenheid sal nie tot stand kom as daar nie voor gearbei word nie. Die Afrikaner moet weer ingewortel wees in 'n eie volksbodem, hy moet weer te staan kom in die volle lewe van 'n Afrikaanse volk. Sy beginsels en tradisies moet hy kan uitleef in sy daaglikse praktiese lewe, sy volks- en kultuurlewe moet aanpas by sy godsdienstige lewe. Hier is dus oneindig meer nodig as slegs 'n politieke party. Hier moet 'n eie lewensatmosfeer geskep word waar die Afrikaner hom sal tuisvoel saam met sy mede-Afrikaners. Dit kan alleen geskied as daar 'n ware Afrikaanse volksbeweging ontstaan, waarin ons Afrikaners ons ideale kan naleef en ons as mekaar se hoeders kan optree en as volk leiding en rigiing gee in Suid-Afrika. 'n Volksbeweging wat ons Afrikaners geestelik en stofllk saambind tot 'n kragtige eenheid-dit is wat ons wil he. Nie Fascisme of Nasionaal-Sosialisme of enige ander-isme nie, maar enkel en alleen 'n volksbeweging waarin die ganse volk saam marsjeer op die pad van Suid-Afrika.

Maar, sal baie vra, op watter beginsels moet so'n beweging gefundeer wees? Vir ons Calviniste is hierdie vraag van baie groot belang. Ons kan alleen 'n saak bevorder as die beginsels suiwer en reg is. Tog glo ons nie dat ons volk baie moeilikheid sal ondervind om te kom tot 'n gesonde eenheidsbasis nie. Ons volk sal self die weg vind net soos ons gedoen het toe ons die sogenoemde grondwet as grondslag aanvaar het. Net soos ons volk met die eeufees saamgebind was deur dieselfde beginsels, net so sal ons ook in 'n ware volksbeweging saam voel vir dieselfde ideale. Die O.B. sê hy staan nog by hierdie selfde grondwet en die H.N.P. sal dit ook wel as grondslag aanvaar. Daar sal wel eenheid kan wees oor watter magte ons aan die staat wil toeken en in hoeverre sosialisering van ons volkslewe moet plaasvind. Hiervoor is daar nie sulke groot verskille onder ons Afrikaners nie.

'n Baie moeiliker vraag is hoe so 'n volksbeweging 'n werklikheid gaan word. Die O.B. was 'n volksbeweging waarin die grootste gros van Afrikaners saamgesnoer was, vandag nog werk dit vir volkseenheid en wil dit deurgaan as 'n volksbeweging. Maar as dit nou blyk dat die O.B. onder gegewe omstandighede nie die angewese liggaam is om die leiding te neem on ware volkseenheid tot stand te bring nie, is ons seker daarvan dat die leiers hiervan met ander sal saamwerk oll so'n volksbeweging in die lewe te roep. Vir ons is dit nie die groot vraag wie of wat die leiding ncem nie. Volkseenheid moet vir ons hoër staan as persoonlike of organisasie-belange. 
Dit skyn vir ons of dit die aangewese weg is dat ons leiers bymekaar moet kom om ons volk te verenig in 'n eenheidsbeweging. Van verskillende kante is daar reeds geprobeer om dit te verwesenlik maar tot hiertoe sonder enige sukses. Dit skyn asof die moeilikheid by die leiers lê. Of die leiers moet bymekaar kom of daar moet 'n ware volksleier opstaan wat al die ander leiers oorskadu.

Ons kan moeilik 'n oplossing aan die hand gee. Al wat ons nou kan doen, is om elkeen te arbei vir volkseenheid en vir 'n volksbeweging. Dit moet gedoen word deur ons politieke, kulturele en godsdienstige leiers. Die persone wat volkseenheid teenwerk of wat die verwerkliking hiervan onmoontlik maak, sal veroordeel staan voor God en die Afrikanervolk. Dit dan beskou ons nou vir hierdie tyd as die allervernaamste roeping en taak van alle Afrikaners. Later kan dit miskien te laat wees. Wil ons gevrywaar word van die gevare van kapitalisme en kommunisme, wil ons nie oorheers word deur die uitlanders wat nog steeds ons land instroom, en wil ons as 'n Afrikaanse volk bly voortbestaan, moet ons saamstaan en saamgesnoer word in 'n hegte volksbeweging. As ons dit nie doen nie, is dit klaarpraat met ons en is ons gedoem tot 'n gewisse en smadelike ondergang.

Siloam.

H. DU PLESSIS. 